\title{
KUALITAS AIR DANAU SUNTER BERDASARKAN PARAMETER FISIKA DAN KIMIA MENGGUNAKAN METODE INDEKS PENCEMARAN
}

\author{
Agung Aji Saputro, Sunaryo, Riser Fahdiran \\ Program Studi Fisika, FMIPA Universitas Negeri Jakarta, Jl. Rawamangun Muka No. 01, Rawamangun \\ 13220, Indonesia \\ Email: a)agungsaputro67@gmail.com
}

\begin{abstract}
Abstrak
Kualitas Air Danau Sunter Berdasarkan Parameter Fisika dan Kimia Menggunakan Metode Indeks Pencemaran. Skripsi, Program Studi Fisika, Fakultas Matematika dan Ilmu Pengetahuan Alam, Universitas Negeri Jakarta. Desember 2020. Mengetahui kondisi kualitas air Danau Sunter menggunakan data sekunder Dinas Lingkungan Hidup DKI Jakarta pada bulan April tahun 2019 dengan metode Indeks Pencemaran. Hasil yang diperoleh adalah berdasarkan uji parameter air dari arah inlet hingga outlet secara keseluruhan masih dalam kondisi baik. Hanya saja terdapat dua parameter yang kondisinya tidak sesuai dengan peruntukan baku mutu air kelas tiga atau golongan $\mathrm{C}$ yaitu suhu dan BOD. Berdasarkan penilaian status mutu air dengan metode Indeks Pencemaran menunjukkan semua stasiun atau titik pengambilan sampel dari inlet hingga outlet dalam kondisi tercemar ringan.
\end{abstract}

Kata Kunci: Kualitas Air, Danau Sunter, Indeks Pencemaran

\begin{abstract}
Sunter Lake Water Quality Based on Physical and Chemical Parameters Using the Pollution Index Method. Thesis, Physics Study Program, Faculty of Mathematics and Sciences, State University of Jakarta. December 2020. Knowing the condition of Lake Sunter water quality using secondary data from the Environment Agency of DKI Jakarta in April 2019 using the Pollution Index method. The results obtained are based on the water parameter test from the inlet to the outlet as a whole is still in good condition. It's just that there are two parameters whose conditions are not by the designation of class three or class $\mathrm{C}$ water quality standards, that is temperature and BOD. Based on the assessment of water quality status using the Pollution Index method, it shows that all stations or sampling points from the inlet to the outlet are lightly polluted.
\end{abstract}

Keywords: Water quality, Lake Sunter, Pollution Index

\section{PENDAHULUAN}

Berdasarkan dengan UU. No. 7 Tahun 2004 tentang Sumber Daya Air, pengelolaan danau atau situ terdiri atas tiga komponen utama yaitu konservasi, pemanfaatan, dan pengendalian daya rusak air. Dalam Peraturan Pemerintah Nomor 82 Tahun 2001 menyatakan bahwa upaya pengelolaan 
kualitas air pada sungai dan danau antara lain dengan menetapkan daya tampung sungai atau danau, menetapkan peruntukan sungai atau danau yang disertai dengan penerapan baku mutu perairan [1]. Danau sendiri merupakan penampung air tawar yang memiliki bentuk cekungan dan dikelilingi oleh daratan, baik terbentuk secara alami maupun buatan. Danau menempati porsi yang sangat penting sebagai penunjang kehidupan manusia bagi untuk pertanian, rekreasi, air minum, dan kebutuhan hidup manusia lainnya. Manfaat lainnya juga sebagai penampung air hujan dan sumber air saat musim kemarau datang. Tetapi apabila terjadi kerusakan di sekitarnya maka secara tidak langsung akan mempengaruhi kondisi danau tersebut [2].

Berdasarkan pemanfaatannya, sungai dan danau di DKI Jakarta digunakan untuk keperluan rumah tangga, usaha perikanan, pertanian, peternakan, industri, pelayaran rekreasi, pembangkit listrik, penampung air serta di beberapa tempat digunakan sebagai tempat pembuangan sampah rumah tangga dan industri. Sebagaimana kegunaan yang harus dimanfaatkan dengan sebaik-baiknya oleh penduduk sekitar, kualitas maupun kuantitas danau di DKI Jakarta semakin menurun [3]. Jumlah area resapan air di DKI Jakarta masih tergolong sangat sedikit, ditengah maraknya pembangunan baik yang sudah selesai maupun daam proses pembangunan. Danau Sunter merupakan salah satu resapan air yang ada di wilayah Kecamatan Tanjung Priok, Kelurahan Sunter Jakarta Utara. Namun, keadaannya sekarang semakin menurun karena menjadi salah satu penampungan limbah yang notabene berada di tengah-tengah kawasan pabrik dan area pergudangan. Hal ini menyebabkan menurunnya daya dukung kualitas air danau karena penanganan limbah yang tidak diolah dan langsung dibuang begitu saja membuat ekosistem Danau Sunter menjadi terganggu sehingga mengakibatkan penurunan fungsi ekologi di kawasan tersebut. Hal ini tentu saja sangat mempengaruhi kualitas air di perairan sekitar Danau Sunter tersebut [4].

\section{METODOLOGI}

Metode penelitian yang digunakan adalah metode Eksperimen dengan melakukan pengujian kualitas air berdasarkan parameter fisika dan kimia. Dengan berpedoman pada Peraturan Pemerintah No. 82 Tahun 2001 tentang Pengelolaan Kualitas Air dan Pengendalian Pencemaran Air, Keputusan Gubernur DKI Jakarta No. 582 Tahun 1995 tentang Penetapan Peruntukan dan Baku Mutu Air Sungai atau Badan Air serta Baku Limbah Cari di Wilayah DKI Jakarta, dan Keputusan Menteri Lingkungan Hidup No. 115 Tahun 2003 tentang Pedoman Penentuan Status Mutu Air dan Standar Nasional Indonesia (SNI) 6989.57:2008 Bagian 57 Metode Pengambilan sampel Air Permukaan.

Teknik Pengumpulan data sesuai pada tiap-tiap parameter diantaranya ialah pada parameter Fisika ,suhu dan kekeruhan serta parameter Kimia $\mathrm{pH}$ dilakukan melalui cara in situ yaitu pengukuran secara langsung di lokasi penelitian. Pada parameter Fisika, TDS dan TSS serta parameter Kimia yang lain, DO, BOD, COD, Kadmium, Tembaga, dan Nitrit dengan cara ex situ yaitu hasil sampel merupakan data dari hasil laboratorium.

Untuk analisis data dilakukan secara umum, yaitu analisis fisis dan kimiawi berdasarkan nilai tiap-tiap parameter yang diperoleh lalu dibandingkan dengan kriteria mutu air dalam Peraturan Pemerintah Nomor 82 Tahun 2001 dan Keputusan Gubernur DKI Jakarta Nomor 582 Tahun 1995, yang dapat dilihat pada TABEL 1 berikut.

TABEL 1. Kriteria Mutu Air Berdasarkan PP No. 82/2001

\begin{tabular}{lcccc}
\hline \multirow{2}{*}{\multicolumn{1}{c}{ Parameter }} & \multirow{2}{*}{ Satuan } & \multicolumn{3}{c}{ Kelas } \\
\cline { 3 - 5 } Suhu & & I & II & III \\
\hline $\mathrm{pH}$ & ${ }^{\circ} \mathrm{C}$ & Dev 3 & Dev 3 & Dev 3 \\
\hline DO (Oksigen Terlarut) & - & $6-9$ & $6-9$ & $6-9$ \\
\hline TDS (Zat Padat Terlarut) & $\mathrm{mg} / \mathrm{L}$ & 6 & 4 & 3 \\
\hline Kekeruhan & $\mathrm{mg} / \mathrm{L}$ & 1000 & 1000 & 1000 \\
\hline TSS (Zat Padat Tersuspensi) & $\mathrm{NTU}$ & 5 & 100 & 100 \\
\hline BOD (Jumlah Oksigen Terlarut) & $\mathrm{mg} / \mathrm{L}$ & 50 & 50 & 400 \\
\hline COD (Jumlah Oksigen diperlukan) & $\mathrm{mg} / \mathrm{L}$ & 2 & 3 & 6 \\
\hline Kadmium & $\mathrm{mg} / \mathrm{L}$ & 10 & 25 & 50 \\
\hline Tembaga & $\mathrm{mg} / \mathrm{L}$ & 0,01 & 0,01 & 0,01 \\
\hline Nitrit & $\mathrm{mg} / \mathrm{L}$ & 0,02 & 0,02 & 0,02 \\
\hline
\end{tabular}




\section{HASIL DAN PEMBAHASAN}

Berdasarkan data insitu yang diperoleh dari Dinas Lingkungan Hidup DKI Jakarta pada TABEL 2 merupakan hasil dari tiga titik sampel, diantaranya pada stasiun inlet atau masukan aliran air, tengah danau, dan outlet atau keluaran aliran air.

TABEL 2. Data Kualitas Air Danau Sunter

\begin{tabular}{lcccc}
\hline \multicolumn{1}{c}{ Parameter } & Satuan & Inlet & Tengah & Outlet \\
\hline Suhu & ${ }^{\circ} \mathrm{C}$ & 31,5 & 31,7 & 31,8 \\
\hline $\mathrm{pH}$ & - & 8,4 & 8,6 & 8,6 \\
\hline DO (Oksigen Terlarut) & $\mathrm{mg} / \mathrm{L}$ & 5 & 5,1 & 4,7 \\
\hline TDS (Zat Padat Terlarut) & $\mathrm{mg} / \mathrm{L}$ & 645 & 645 & 644 \\
\hline Kekeruhan & $\mathrm{NTU}$ & 19,5 & 17,01 & 19,2 \\
\hline TSS (Zat Padat Tersuspensi) & $\mathrm{mg} / \mathrm{L}$ & 32 & 28 & 27 \\
\hline BOD (Jumlah Oksigen Terlarut) & $\mathrm{mg} / \mathrm{L}$ & 9,08 & 8,33 & 8,03 \\
\hline COD (Jumlah Oksigen yang diperlukan) & $\mathrm{mg} / \mathrm{L}$ & 23 & 27 & 23 \\
\hline Kadmium $(\mathrm{Cd})$ & $\mathrm{mg} / \mathrm{L}$ & 0,006 & 0,008 & 0,005 \\
\hline Tembaga $(\mathrm{Cu})$ & $\mathrm{mg} / \mathrm{L}$ & 0,015 & 0,016 & 0,018 \\
\hline Nitrit $\left(\mathrm{NO}_{2}\right)$ & $\mathrm{mg} / \mathrm{L}$ & 0,005 & 0,004 & 0,004 \\
\hline
\end{tabular}

Sumber: Dinas Lingkungan Hidup DKI Jakarta, April 2019

Berdasarkan Peraturan Pemerintah atau PP Republik Indonesia Nomor 82 Tahun 2001 Tentang Pengelolaan Kualitas Air dan Pengendalian Pencemaran Air, Keputusan Gubernur DKI Jakarta Nomor 582 Tahun 1995 Tentang Penetapan Peruntukan dan Baku Mutu Air Sungai atau Badan Air serta Baku Limbah Cair di Wilayah DKI Jakarta.

Danau di wilayah DKI Jakarta berdasarkan peraturan tersebut dikategorikan ke dalam golongan C yang peruntukannya sebagai perikanan dan peternakan (Pasal 3 Pergub DKI No 582 Tahun 1995). Berdasarkan Peraturan Pemerintah Republik Indonesia Nomor 82 Tahun 2001 pasal 8 pun sama, yaitu diklasifikasikan dalam kelas tiga yang peruntukannya untuk budidaya ikan air tawar, peternakan, air untuk mengairi pertanaman, dan atau peruntukan lain yang mempersyaratkan mutu air yang sama dengan kegunaan tersebut.

Pada pengukuran kualitas fisika air Danau Sunter meliputi pengujian Suhu, Kekeruhan, TDS (Total Disolved Solids/Zat Padat Terlarut), dan TSS (Total Suspended Solids/Zat Padat Tersuspensi). Pada pengukuran kualitas kimia air Danau Sunter meliputi pengujian pH (Derajat Keasaman), DO (Dissolved Oxygen/Oksigen Terlarut), BOD (Biochemical Oxygen Demand/Kebutuhan Oksigen Biokimia), COD (Chemical Oxygen Demand/Jumlah Oksigen yang diperlukan), Kadmium, Tembaga, dan Nitrit. Berdasarkan hasil pengujian diperoleh hasil sebagai berikut:

\section{Suhu}

Sebaran nilai hasil uji parameter suhu air Danau Sunter dapat dilihat pada GAMBAR 1 di bawah ini.

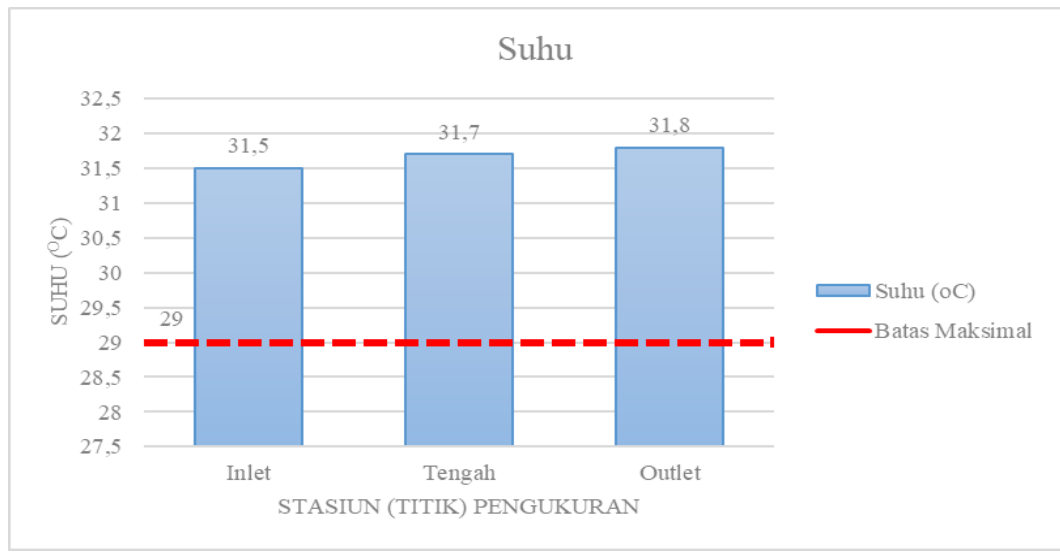

GAMBAR 1. Histogram Suhu Air Danau Sunter

Hasil pengukuran suhu di tiga stasiun (titik) pada perairan danau sunter secara keseluruhan tidak menunjukkan variasi nilai yang besar, bahkan relatif stabil berkisar antara $31,5{ }^{\circ} \mathrm{C}-31,8{ }^{\circ} \mathrm{C}$ dengan 
rata-rata $31,67{ }^{\circ} \mathrm{C}$. Suhu terendah yaitu $31,5{ }^{\circ} \mathrm{C}$ pada stasiun Inlet dan suhu tertinggi yaitu $31,8{ }^{\circ} \mathrm{C}$ pada stasiun Outlet. Berdasarkan Peraturan Pemerintah Nomor 82 Tahun 2001, kisaran suhu untuk kelas 3 adalah deviasi 3 dari keadaan temperatur alamiah di lingkungan setempat, yaitu 23 oC -29 oC. Dengan demikian, suhu pada perairan danau sunter tidak memenuhi krteria air baku kelas 3 sesuai peruntukan, karena melebihi batas maksimalnya.

Suhu merupakan salah satu faktor lingkungan yang memiliki peran penting dalam mengendalikan ekosistem suatu perairan. Berdasarkan hasil pengukuran suhu pada lokasi pengambilan sampel di Danau Sunter tidak memenuhi baku mutu kelas 3. Suhu mempunyai peranan penting dalam menentukan pertumbuhan ikan yang dibudidaya, kisaran yang baik untuk menunjang pertumbuhan optimal adalah 28 oC -32 oC [5]. Hal ini menunjukkan bahwa keadaan suhu air di Danau Sunter masih layak dan memenuhi syarat untuk dilakukan kegiatan yang berkaitan dengan usaha budidaya ikan.

Peningkatan suhu juga menyebabkan terjadinya peningkatan dekomposisi bahan organik yang disebabkan oleh mikroba. Kisaran suhu optimum bagi pertumbuhan fitoplankton di perairan adalah 20 oC - 30 oC, Sehingga suhu air di Danau Sunter dapat dikatakan tidak mendukung dalam hal pertumbuhan fitoplankton, karena suhu nya diatas 30 oC [6][7].

\section{Kekeruhan}

Sebaran nilai hasil uji parameter kekeruhan air Danau Sunter dapat dilihat pada GAMBAR 2 di bawah ini.

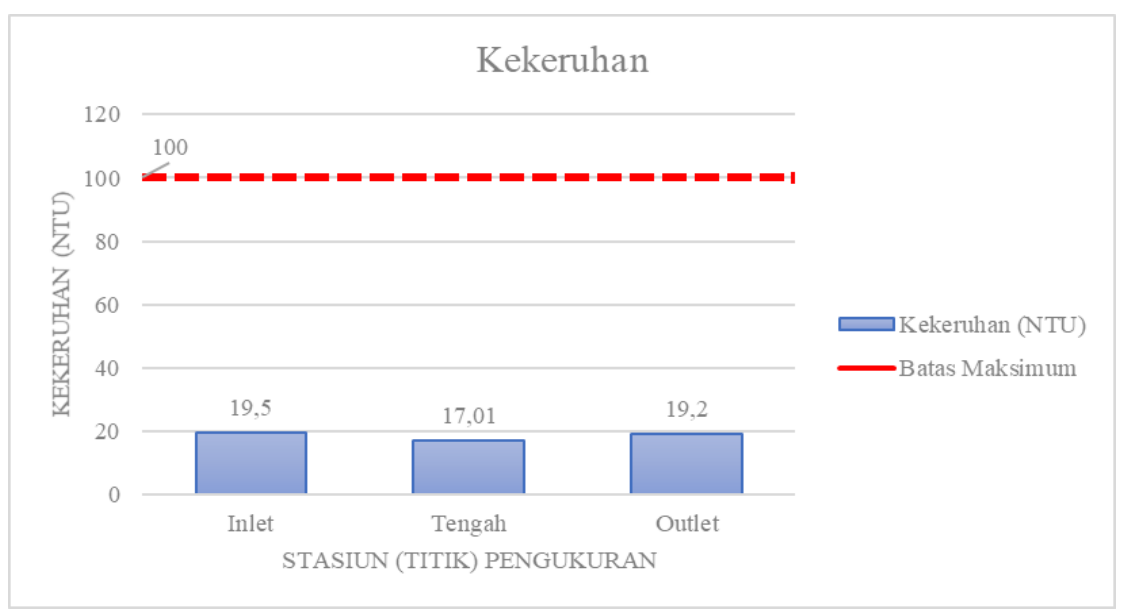

GAMBAR 2. Histogram Kekeruhan Air Danau Sunter

Hasil pengukuran kekeruhan di tiga stasiun (titik) pada perairan Danau Sunter menunjukkan variasi nilai yang tidak terlalu besar dan relatif stabil, yaitu 17,01 - 19,5 NTU, dengan rata-rata 18,57 NTU. Nilai terendah terdapat pada titik tengah yaitu 17,01 NTU dan nilai tertinggi pada titik Inlet yaitu 19,5 NTU. Pada titik tertinggi yakni di sekitar wilayah Inlet terdapat aktifitas masyarakat sekitar yang sering digunakan sebagai tempat pembuangan sampah. Selain itu, nilai kekeruhan tinggi pada inlet juga dapat dikarenakan merupakan tempat permulaan aliran air danau sunter sehingga terjadi penumpukan sedimen. Mengukur kekeruhan berarti menghitung banyaknya bahan-bahan terlarut di dalam air seperti lumpur, alga (ganggang), detritus dan bahan-bahan kotoran lainnya. Akibat tingkat kekeruhan danau menyebabkan cahaya matahari yang masuk ke permukaan air berkurang, sehingga mengakibatkan menurunnya proses fotosintesis oleh tumbuhan air, dan menyebabkan suplai oksigen yang diberikan oleh tumbuhan dari proses fotosintesis berkurang. Bahan-bahan terlarut dalam air juga menyerap panas yang mengakibatkan suhu air meningkat sehingga jumlah oksigen terlarut dalam air berkurang [8].

Kekeruhan yang terjadi pada perairan danau sunter lebih banyak disebabkan oleh bahan tersuspensi berupa koloid dan partikel-partikel halus. Kekeruhan yang tinggi dapat mengakibatkan terganggunya sistem osmeregulasi seperti pernafasan dan daya lihat organisme akuatik serta dapat menghambat penetrasi cahaya ke dalam air. Pengaruh kekeruhan yang utama adalah penurunan 
penetrasi cahaya secara mencolok, sehingga aktivitas fotosintesis alga dan fitoplankton menurun, akibatnya produktivitas perairan menjadi turun [9]. Kekeruhan memiliki korelasi positif dengan padatan tersuspensi (TDS), yaitu semakin tinggi nilai kekeruhan maka semakin tinggi pula nilai padatan tersuspensinya. Di mana kekeruhan biasanya terdiri dari partikel anorganik yang berasal dari erosi dan tersuspensi sedimen di dasar danau [8].

Namun, jika dikaitkan dengan hasil pengukuran di Danau Sunter masih cenderung stabil karena nilainya masih di bawah standar baku mutu air golongan C sesuai Peraturan Gubernur DKI Jakarta yaitu 100 dalam skala NTU. Dengan demikian, parameter kekeruhan pada perairan danau sunter masih memenuhi kriteria baku mutu air golongan $\mathrm{C}$ sesuai peruntukan, karena tidak melebihi batas maksimumnya.

\section{TDS (Total Disolved Solids/Zat Padat Terlarut)}

Sebaran nilai hasil uji parameter TDS air Danau Sunter dapat dilihat pada GAMBAR 3 di bawah ini.

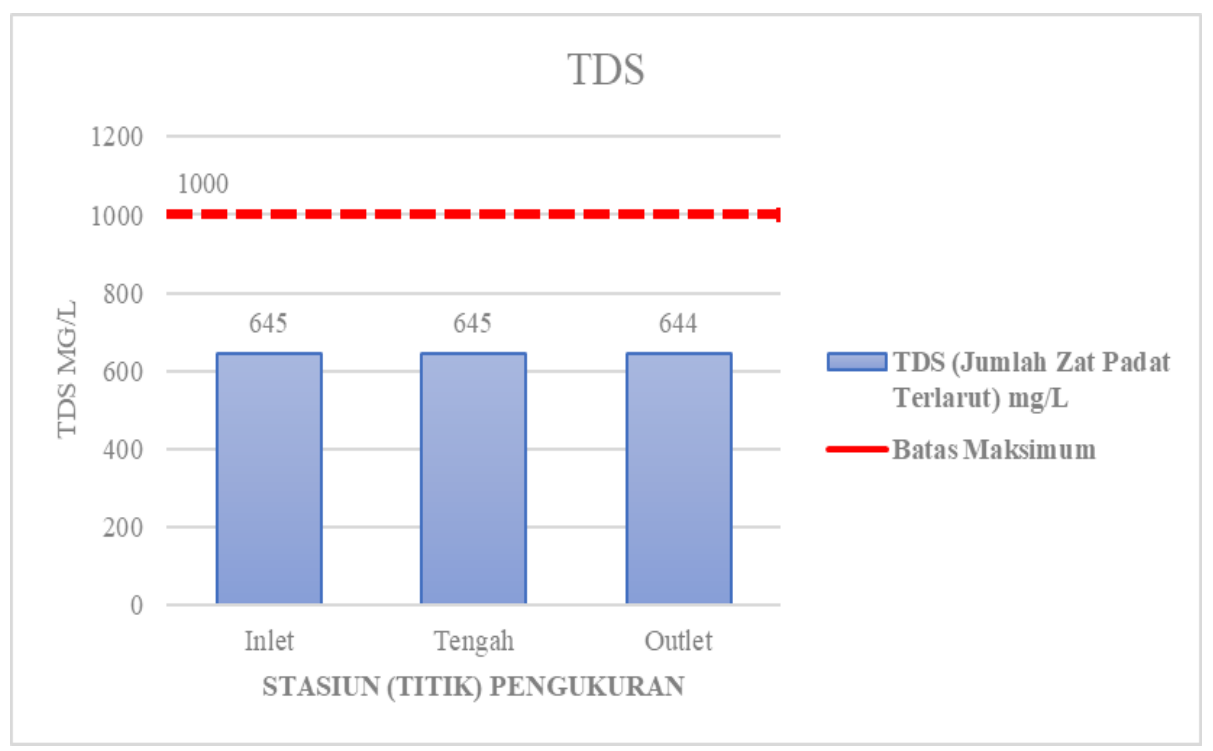

GAMBAR 3. Histogram TDS (Jumlah Zat Padat Terlarut) Air Danau Sunter

Hasil pengukuran total padatan terlarut di tiga stasiun (titik) pada perairan Danau Sunter menunjukkan variasi nilai yang tidak terlalu besar dan relatif sama, yaitu $644-645 \mathrm{mg} / \mathrm{L}$, dengan rata-rata $644,6 \mathrm{mg} / \mathrm{L}$. Nilai terendah terdapat pada titik outlet yaitu $644 \mathrm{mg} / \mathrm{L}$ dan nilai tertinggi pada titik inlet dan tengah dengan nilai sama yaitu $645 \mathrm{mg} / \mathrm{L}$. Berdasarkan gambar di atas, hasil pengukuran total padatan terlarut di tiga titik secara keseluruhan masih berada jauh di bawah 1000 mg/L. Berdasarkan Peraturan Pemerintah Nomor 82 Tahun 2001, kisaran residu terlarut untuk kelas 3 adalah $1000 \mathrm{mg} / \mathrm{L}$. Dengan demikian, hasil uji parameter TDS Danau Sunter masih berada di bawah batas maksimum baku mutu yang dipersyaratkan. Nilai TDS pada Danau Sunter khususnya di titik inlet memiliki nilai TDS yang cukup besar, dan hampir semuanya sama baik tengah maupun outlet. Khusus pada inlet disebabkan adanya masukan aliran sungai yang membawa ion-ion anorganik seperti sodium, kalsium, sulfat, bikarbonat dan lain - lain. Sedangkan untuk nilai TDS yang rendah disebabkan lokasi yang jauh dari aktivitas manusia dan jauh dari inlet sehingga beban masukan ion-ion anorganik lebih rendah. Hasil penelitian lain yang melaporkan nilai TDS perairan Prapat Danau Toba lebih tinggi pada stasiun dengan aktivitas manusia yang tinggi dibandingkan dengan tengah atau jauh dari aktivitas manusia [10]. Kaitannya pada Danau Sunter Sendiri adalah daerah disekitarnya dan tengah dijadikan tempat rekreasi serta olahraga bagi masyarakat sekitar.

Jumlah padatan terlarut pada air sungai lebih tinggi daripada air danau karena banyaknya aktivitas masyarakat dan aktivitas perindustrian. Jumlah padatan terlarut pada air danau berasal dari sisa aktivitas perikanan dan sisa metabolisme ikan pada lahan perikanan [11]. Begitu juga yang terjadi 
pada sekitar Danau Sunter yang merupakan salah satu wilayah perikanan. Namun, jumlah padatan terlarut dari aktivitas perikanannya masih bisa dikendalikan.

\section{TSS (Total Suspended Solids/Total Zat Padat Tersuspensi)}

Sebaran nilai hasil uji parameter TSS air Danau Sunter dapat dilihat pada GAMBAR 4 di bawah ini.

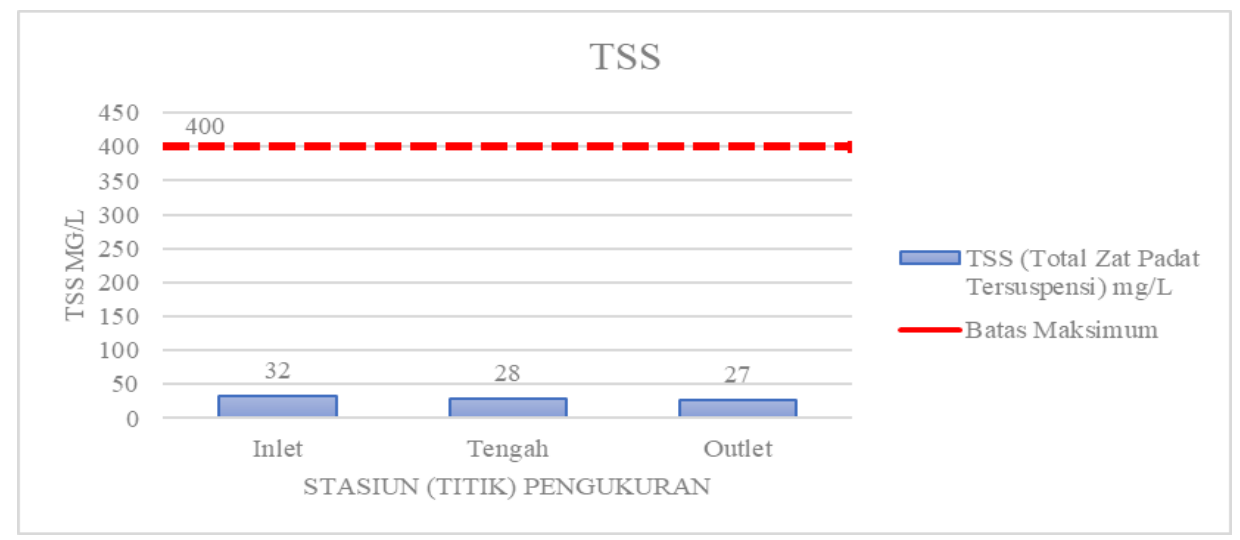

GAMBAR 4. Histogram TSS (Jumlah Zat Padat Tersuspensi) Air Danau Sunter

Hasil pengukuran total padatan tersuspensi di tiga stasiun (titik) pada perairan Danau Sunter menunjukkan variasi nilai yang tidak terlalu besar dan terjadi penurunan yang juga tidak terlalu signifikan yaitu $27-32 \mathrm{mg} / \mathrm{L}$, dengan rata-rata nilai $29 \mathrm{mg} / \mathrm{L}$. Nilai terendah terdapat pada titik outlet yaitu $27 \mathrm{mg} / \mathrm{L}$ dan nilai tertinggi pada titik inlet dengan nilai $32 \mathrm{mg} / \mathrm{L}$. Berdasarkan gambar di atas, hasil pengukuran total padatan tersuspensi di tiga titik secara keseluruhan masih berada jauh di bawah $400 \mathrm{mg} / \mathrm{L}$. Berdasarkan Peraturan Pemerintah Nomor 82 Tahun 2001, kisaran residu tersuspensi untuk kelas 3 adalah $400 \mathrm{mg} / \mathrm{L}$. Dengan demikian, hasil uji parameter TSS Danau Sunter masih berada di bawah batas maksimum baku mutu yang dipersyaratkan.

Besar nilai TSS pada inlet terjadi karena masukan air beserta unsur lain dari berbagai sungai disekitar Danau Sunter, sehingga terjadi penumpukan dan peningkatan padatan tersuspensi terutama yang berupa bahan anorganik (liat dan butiran pasir). Selain itu, TSS terdiri dari jasad renik, yang terutama disebabkan oleh kikisan tanah atau erosi yang terbawa ke badan air.

Nilai TDS air Danau Sunter yang didapatkan lebih tinggi dibandingkan nilai TSS meskipun masih di bawah batas baku yang dipersyaratkan. Hal ini menggambarkan bahwa padatan yang masuk ke Danau Sunter lebih banyak yang berbentuk padatan dan ukurannya kecil (padatan terlarut). Dominasi padatan terlarut tersebut berasal dari limbah-limbah organik dari aliran sungai menuju danau maupun sekitar Danau Sunter.

Rendahnya nilai TSS juga disebabkan padatan tersuspensi tersebut dipengaruhi oleh asupan daratan melalui aliran sungai yang menuju Danau Sunter. Sehingga tidak terlalu berpengaruh terhadap kehidupan biota yang hidup di perairan tersebut. Rendahnya nilai TSS mempengaruhi nilai kecerahan dan sangat erat dengan kaitannya dengan kekeruhan karena kekeruhan dapat menghambat masuknya cahaya ke dalam perairan. Berdasarkan nilai kesesuaian perairan untuk kepentingan perikanan dengan nilai TSS kandungan padatan tersuspensi air Danau Sunter sedikit berpengaruh 25 $-80 \mathrm{mg} / \mathrm{L}$ terhadap kepentingan perikanan [12].

\section{5. pH (Derajat Keasaman)}

Sebaran nilai hasil uji parameter pH air Danau Sunter dapat dilihat pada GAMBAR 5 di bawah ini. 


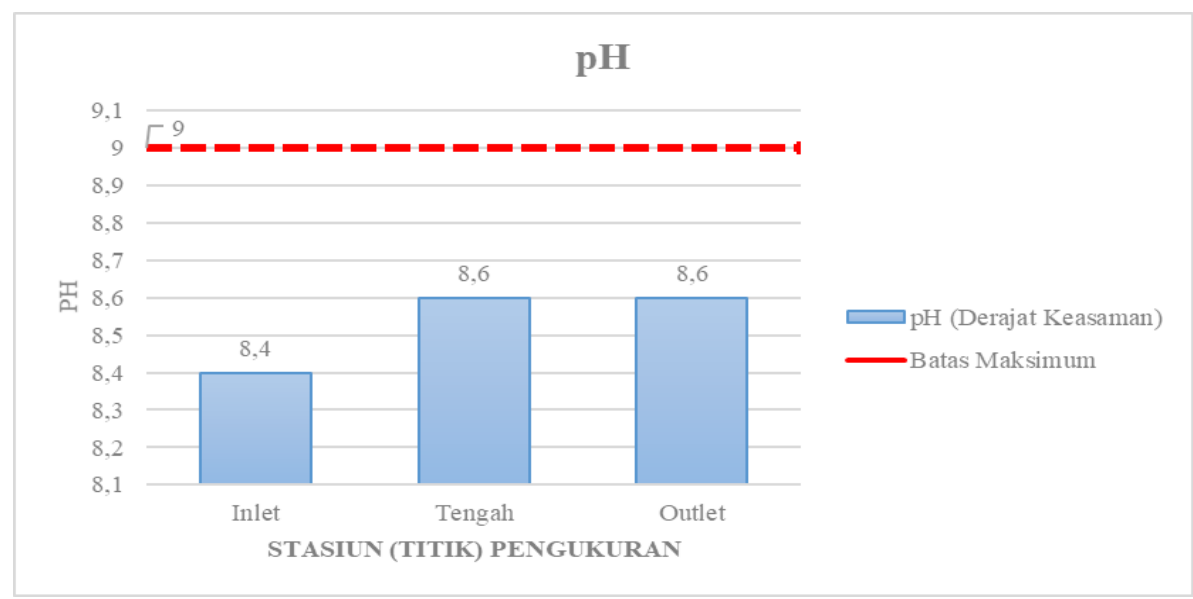

GAMBAR 5. Histogram pH (Derajat Keasaman) Air Danau Sunter

Hasil pengukuran $\mathrm{pH}$ di tiga stasiun (titik) pada perairan Danau Sunter menunjukkan variasi nilai yang tidak terlalu besar dan terjadi peningkatan yang juga tidak terlalu signifikan yaitu $8,4-8,6$. Rata-rata nilai $\mathrm{pH}$ dari ketiga titik pengukuran adalah 8,53 . Nilai terendah terdapat pada titik inlet yaitu 8,4 dan nilai tertinggi pada titik outlet dan tengah dengan nilai 8,6. Berdasarkan gambar 5 di atas, hasil pengukuran $\mathrm{pH}$ di tiga titik secara keseluruhan masih berada di bawah batas maksimum. Berdasarkan Peraturan Pemerintah Nomor 82 Tahun 2001, kisaran pH untuk kelas 3 adalah $6-9$. Dengan demikian, hasil uji parameter $\mathrm{pH}$ Danau Sunter masih berada di bawah batas maksimum baku mutu yang dipersyaratkan dan masih sesuai dengan baku mutu kelas 3 yang di tetapkan.

Kenaikan $\mathrm{pH}$ pada perairan biasanya akan diikuti dengan semakin kecilnya kelarutan dari senyawa-senyawa logam. Perubahan tingkat stabil dari kelarutan tersebut biasanya terlihat dalam bentuk pergeseran persenyawaan [13]. Kenaikan $\mathrm{pH}$ pada titik tengah dan outlet disebabkan oleh buangan limbah penduduk yang masuk ke perairan Danau Sunter. Limbah atau sampah tersebut mengandung berbagai macam senyawa kimia yang bersifat basa, seperti deterjen yang dapat meningkatkan nila $\mathrm{pH}$ di perairan Danau Sunter.

Air normal yang memenuhi syarat untuk suatu kehidupan memiliki $\mathrm{pH}$ sekitar 6,5 - 7,5 dan nilai $\mathrm{pH}$ air yang tidak tercemar biasanya mendekati netral $(\mathrm{pH}=7)$ serta memenuhi kehidupan hampir semua organisme air [6]. Sehingga dengan nilai pH air Danau Sunter yang berkisar 8,4-8,6 tidak memenuhi syarat untuk kehidupan organisme air.

Nilai pH Danau Sunter masih lebih sedikit tidak aman untuk kegiatan perikanan, hal ini disebabkan nilai $\mathrm{pH}$ tidak bersifat toksik bagi ikan. $\mathrm{pH}$ yang ideal bagi kehidupan biota air tawar adalah antara 6,8 - 8,5 [5]. pH sangat rendah dapat menyebabkan kelarutan logam-logam dalam air makin besar, yang akan bersifat toksik bagi organisme air, sebaliknya $\mathrm{pH}$ yang tinggi dapat meningkatkan konsentrasi amoniak dalam air yang juga bersifat toksik bagi organisme air.

Secara umum asam dan basa suatu perairan dapat digunakan sebagai indeks kualitas lingkungan. Air dengan kondisi asam akan menyebabkan ikan lemah, lebih mudah terkena infeksi dan tingkat kematian tinggi. Air yang netral atau sedikit basa umumnya lagi sangat ideal. Berubahnya nilai $\mathrm{pH}$ menimbulkan perubahan terhadap keseimbangan kandungan karbondioksida, bikarbonat, dan karbonat di dalam air. Ikan dan biota akuatik lainnya masih dapat mentoleransi lingkungan perairan yang mempunyai $\mathrm{pH}$ antara 4,0 - 11,0 [2]. Berdasarkan gambar 5 perairan Danau Sunter tergolong basa karena melebihi nilai 8 .

\section{DO (Dissolved Oxygen/Oksigen Terlarut)}

Sebaran nilai hasil uji parameter DO air Danau Sunter dapat dilihat pada GAMBAR 6 di bawah ini. 


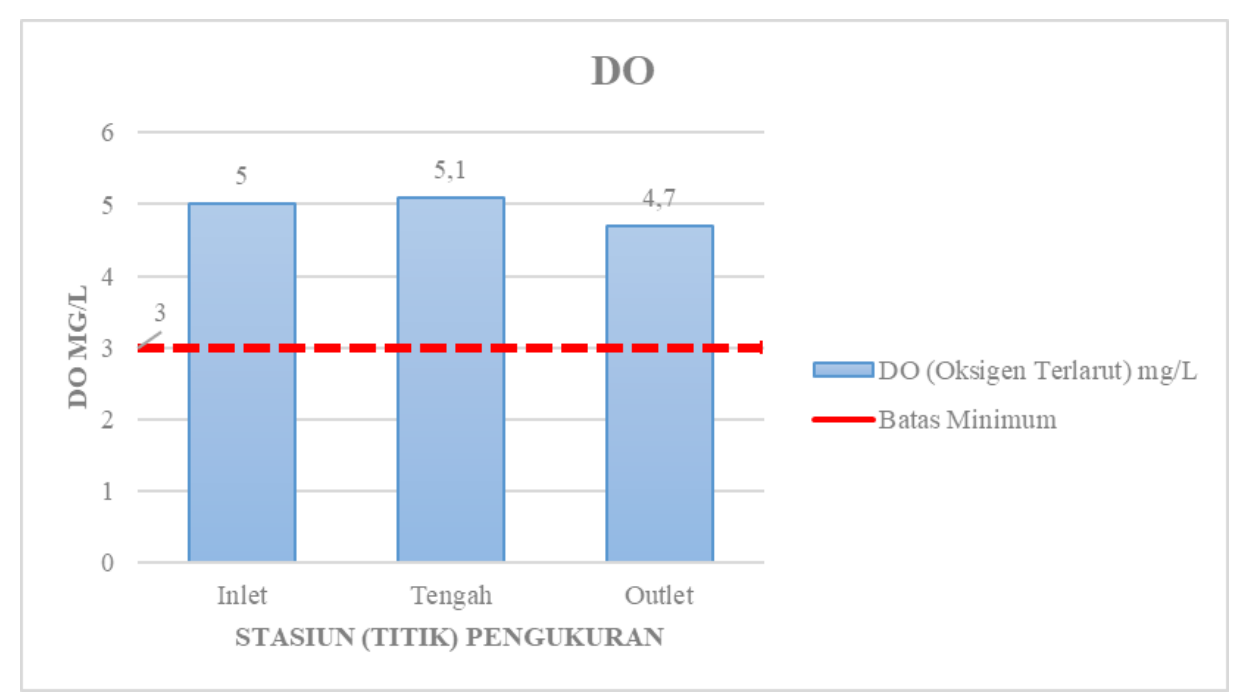

GAMBAR 6. Histogram DO (Oksigen Terlarut) Air Danau Sunter

Pada Hasil pengukuran DO di tiga stasiun (titik) pada perairan Danau Sunter menunjukkan variasi nilai yang tidak terlalu besar yaitu 4,7 $-5,1 \mathrm{mg} / \mathrm{L}$. Rata-rata nilai DO dari ketiga titik pengukuran adalah $4,93 \mathrm{mg} / \mathrm{L}$. Nilai terendah terdapat pada titik outlet yaitu $4,7 \mathrm{mg} / \mathrm{L}$ dan nilai tertinggi pada titik tengah dengan nilai $5,1 \mathrm{mg} / \mathrm{L}$. Berdasarkan gambar 6 di atas, hasil pengukuran DO di tiga titik secara keseluruhan masih berada di atas dari batas minimum. Berdasarkan Peraturan Pemerintah Nomor 82 Tahun 2001, kisaran DO untuk kelas 3 adalah $3 \mathrm{mg} / \mathrm{L}$. Dengan demikian, hasil uji parameter DO Danau Sunter masih berada di atas batas minimum baku mutu yang dipersyaratkan dan masih sesuai dengan baku mutu kelas 3 yang di tetapkan.

Parameter oksigen terlarut atau DO dapat digunakan sebagai indikator tingkat kesegaran air. Oksigen memegang peranan yang begitu penting sebagai salah satu indikator kualitas perairan, karena oksigen terlarut berperan dalam proses oksidasi dan reduksi bahan organik dan anorganik. Karena proses oksidasi dan reduksi inilah maka peranan oksigen terlarut sangat penting untuk membantu mengurangi beban pencemaran pada perairan secara alami [6].

Tingginya nilai DO berhubungan dengan fitoplankton, jika fitoplankton berlimpah maka kadar DO akan tinggi. Tingginya kelimpahan fitoplankton memberikan kontribusi terhadap tingginya kadar oksigen terlarut yang merupakan hasil dari proses fotosintesis [14]. DO Untuk Danau Sunter berkisar antara 4,7 - 5,1 mg/L. untuk kehidupan biota atau ikan kisaran nilai ini termasuk normal. DO yang seimbang untuk hewan budidaya adalah lebih dari $5 \mathrm{mg} / \mathrm{L}$.

Pada umumnya air yang telah tercemar kandungan oksigennya sangat rendah, makin banyak bahan buangan organik di dalam air makin sedikit sisa kandungan oksigen yang terlarut di dalam air. Aktivitas manusia seperti pertanian dan pembuangan limbah menyebabkan penurunan konsentrasi oksigen terlarut [6]. Penurunan nilai DO air Danau Sunter pada titik outlet merupakan akumulasi dari pembuangan limbah domestik di sekitar danau. Perairan dapat dikategorikan sebagai perairan yang baik dan tingkat pencemarannya rendah jika kadar oksigen terlarutnya $>5 \mathrm{mg} / \mathrm{L}$ [7]. Dengan nilai 4,7 $\mathrm{mg} / \mathrm{L}$ pada titik outlet Danau Sunter menandakan bahwa kualitas di sekitar outlet berdasarkan parameter DO memiliki tingkat pencemaran yang sedang.

\section{BOD (Biochemical Oxygen Demand/Kebutuhan Oksigen Biokimia)}

Sebaran nilai hasil uji parameter BOD air Danau Sunter dapat dilihat pada GAMBAR 7 berikut. 


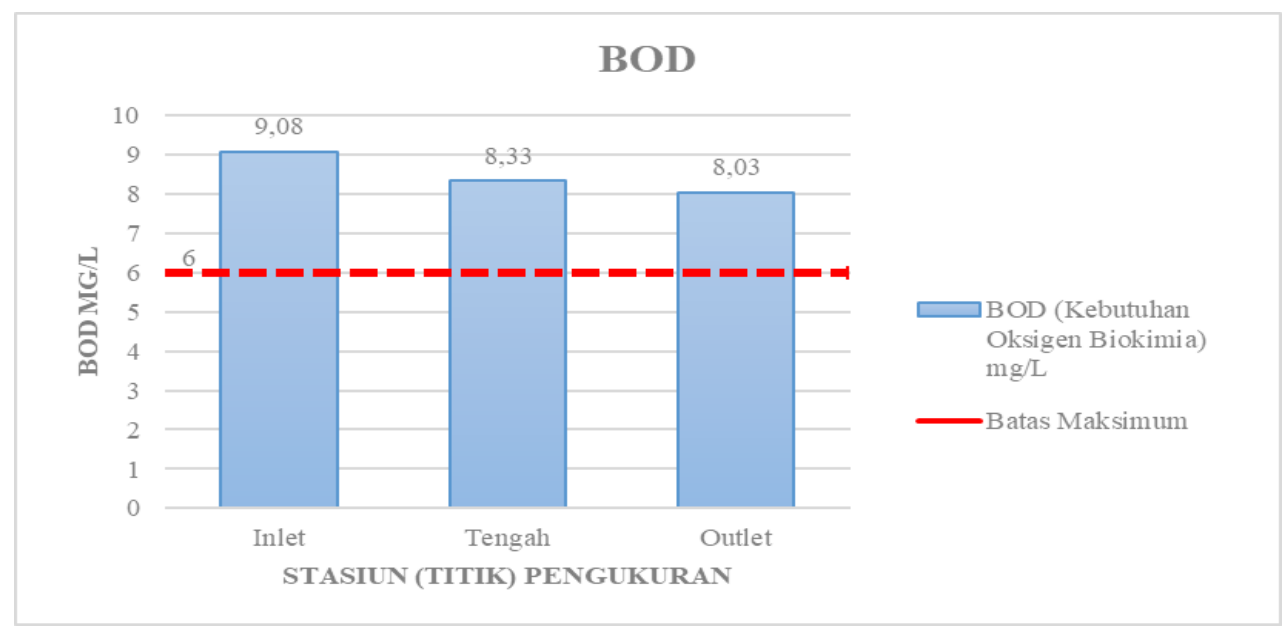

GAMBAR 7. Histogram BOD (Kebutuhan Oksigen Biokimia) Air Danau Sunter

Pada Hasil pengukuran BOD di tiga stasiun (titik) pada perairan Danau Sunter menunjukkan variasi nilai yang tidak terlalu besar yaitu $8,03-9,08 \mathrm{mg} / \mathrm{L}$. Rata-rata nilai BOD dari ketiga titik pengukuran adalah $8,48 \mathrm{mg} / \mathrm{L}$. Nilai terendah terdapat pada titik outlet yaitu $8,03 \mathrm{mg} / \mathrm{L}$ dan nilai tertinggi pada titik inlet dengan nilai $9,08 \mathrm{mg} / \mathrm{L}$. Berdasarkan gambar di atas, hasil pengukuran BOD di tiga titik mengalami penurunan yang tidak signifikan. Berdasarkan Peraturan Pemerintah Nomor 82 Tahun 2001, kisaran batas maksimum BOD untuk kelas 3 adalah 6 mg/L. Dengan demikian, hasil uji parameter BOD Danau Sunter ialah tidak memenuhi kriteria dan melebihi batas maksimum baku mutu yang dipersyaratkan.

Nilai BOD merupakan nilai yang menunjukkan kebutuhan oksigen oleh bakteri aerob untuk mengoksidasi bahan organik di dalam air sehingga secara tidak langsung juga menunjukkan keberadaan bahan organik di dalam air. Tingginya nilai BOD pada stasiun titik inlet disebabkan karena stasiun (titik) inlet merupakan masukan aliran air dari sungai di sekitar Danau Sunter, sehingga terjadi pengendapan dan pengakumulasian limbah organik pada dasar perairan, proses dekomposisi pun meningkat dan menyebabkan kandungan oksigen terlarut menurun. Menumpuknya bahan pencemar organik di perairan akan menyebabkan proses dekomposisi oleh organisme pengurai juga semakin meningkat, sehingga konsentrasi BOD juga meningkat [15].

Selain itu, sumber peningkatan BOD yang tinggi di titik inlet sekitar Danau Sunter juga berasal dari aktivitas wisata dan aktivitas rumah tangga oleh mikroba pendegradasi serta bahan organik yang terdapat di dalam perairan. Pada stasiun titik outlet Danau Sunter yang memiliki nilai BOD lebih rendah karena lebih sedikit bahan organik yang terdapat di dalam air tersebut. Meskipun demikian, titik outlet Danau Sunter masih tetap berada di atas nilai maksimum yang ditetapkan. Limbah domestik mempunyai karakteristik antara lain apabila BOD dan COD tinggi disebabkan karena adanya aktivitas industri yang membuang limbah keperairan [14]. Sehingga semakin besar kadar BOD nya, maka merupakan indikasi bahwa perairan tersebut telah tercemar, khususnya di titik inlet Danau Sunter.

\section{COD (Chemical Oxygen Demand/Jumlah Oksigen yang diperlukan)}

Sebaran nilai hasil uji parameter COD air Danau Sunter dapat dilihat pada GAMBAR 8 berikut. 


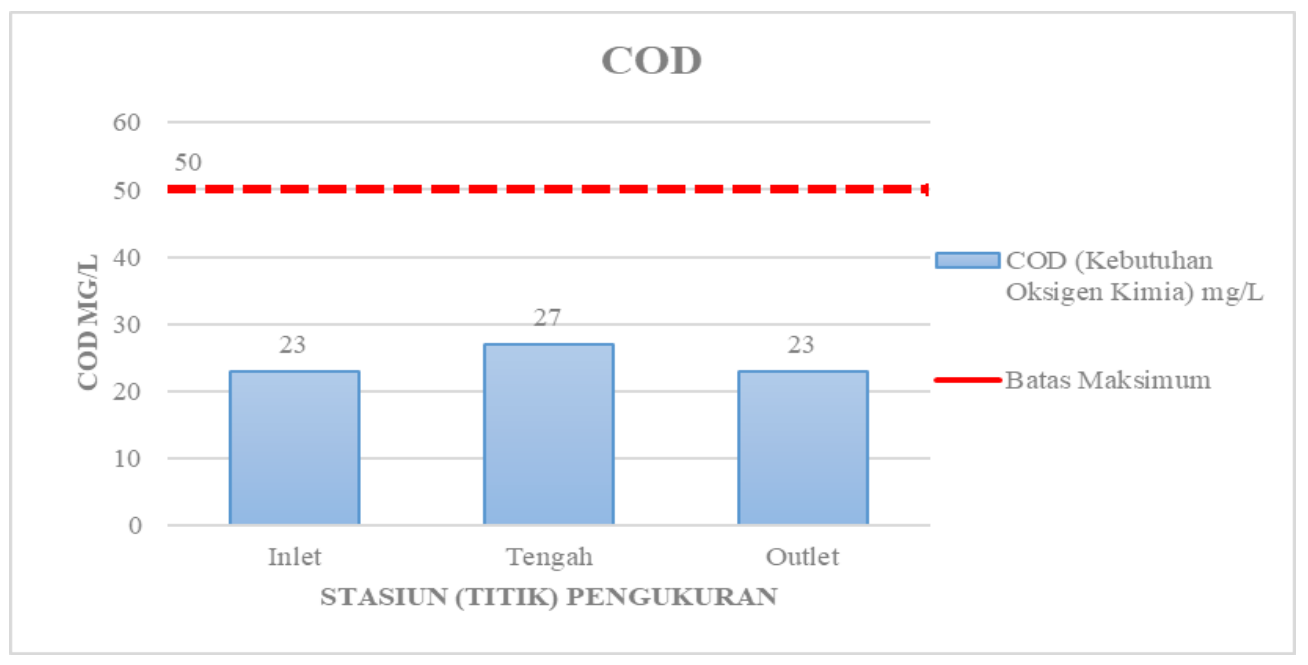

GAMBAR 8. Histogram COD (Kebutuhan Oksigen Kimia) Air Danau Sunter

Pada Hasil pengukuran COD di tiga stasiun (titik) pada perairan Danau Sunter menunjukkan variasi nilai yang tidak terlalu besar yaitu $23-27 \mathrm{mg} / \mathrm{L}$. Rata - rata nilai COD dari ketiga titik pengukuran adalah $24,3 \mathrm{mg} / \mathrm{L}$. Nilai terendah terdapat pada titik inlet dan outlet yaitu $23 \mathrm{mg} / \mathrm{L}$ dan nilai tertinggi pada titik tengah dengan nilai $27 \mathrm{mg} / \mathrm{L}$. Berdasarkan gambar 8 di atas, hasil pengukuran COD di tiga titik mengalami grafik fluktuatif yang nilainya tidak terlalu signifikan. Berdasarkan Peraturan Pemerintah Nomor 82 Tahun 2001, kisaran batas maksimum COD untuk kelas 3 adalah $50 \mathrm{mg} / \mathrm{L}$. Dengan demikian, hasil uji parameter COD Danau Sunter masih memenuhi kriteria dengan tidak melebihi batas maksimum baku mutu yang dipersyaratkan.

Tingginya nilai COD mengindikasikan semakin besar tingkat pencemaran yang terjadi [6]. Perairan yang memiliki nilai COD tinggi tidak diinginkan bagi kepentingan perikanan dan pertanian. Nilai COD pada perairan yang tidak tercemar biasanya kurang dari $20 \mathrm{mg} / \mathrm{L}$, sedangkan pada perairan tercemar dapat lebih dari $200 \mathrm{mg} / \mathrm{L}$ dan pada limbah industri dapat mencapai $60.000 \mathrm{mg} / \mathrm{L}$ [12].

Nilai COD menunjukkan jumlah total oksigen yang dibutuhkan untuk proses oksidasi dan berlangsung secara kimiawi. Dengan demikian maka umumnya nilai COD akan selalu lebih besar dibandingkan dengan nilai BOD, karena nilai BOD terbatas hanya terhadap bahan organik yang dapat diuraikan secara biologis saja, sementara nilai COD menggambarkan kebutuhan oksigen untuk total oksidasi, baik terhadap senyawa yang dapat diuraikan secara biologis maupun terhadap senyawa yang tidak dapat diuraikan secara biologis [16].

Besar nilai COD pada titik tengah yang merupakan pusat perairan Danau Sunter karena banyaknya pengendapan yang terjadi pada titik tengah dan karena tidak terbawa arus danau yang tenang. Sehingga pengendapan dan pengakumulasian limbah organik yang terjadi pada dasar perairan, proses dekomposisi pun meningkat dan menyebabkan kandungan oksigen terlarut menurun. Tinggi rendahnya nilai COD menunjukkan wilayah tersebut banyak terdapat zat-zat organik yang terdiri dari komponen hidrokarbon ditambah sejumlah kecil oksigen, nitrogen, sulfur dan fosfor [17]. Sesuai PP No.82 Tahun 2001 nilai COD tidak boleh lebih dari $50 \mathrm{mg} / \mathrm{L}$. Hal ini mengindikasikan bahwa perairan Danau Sunter masih mampu mendukung kehidupan organisme perairan.

\section{Kadmium}

Sebaran nilai hasil uji parameter Kadmium air Danau Sunter dapat dilihat pada GAMBAR 9 berikut. 


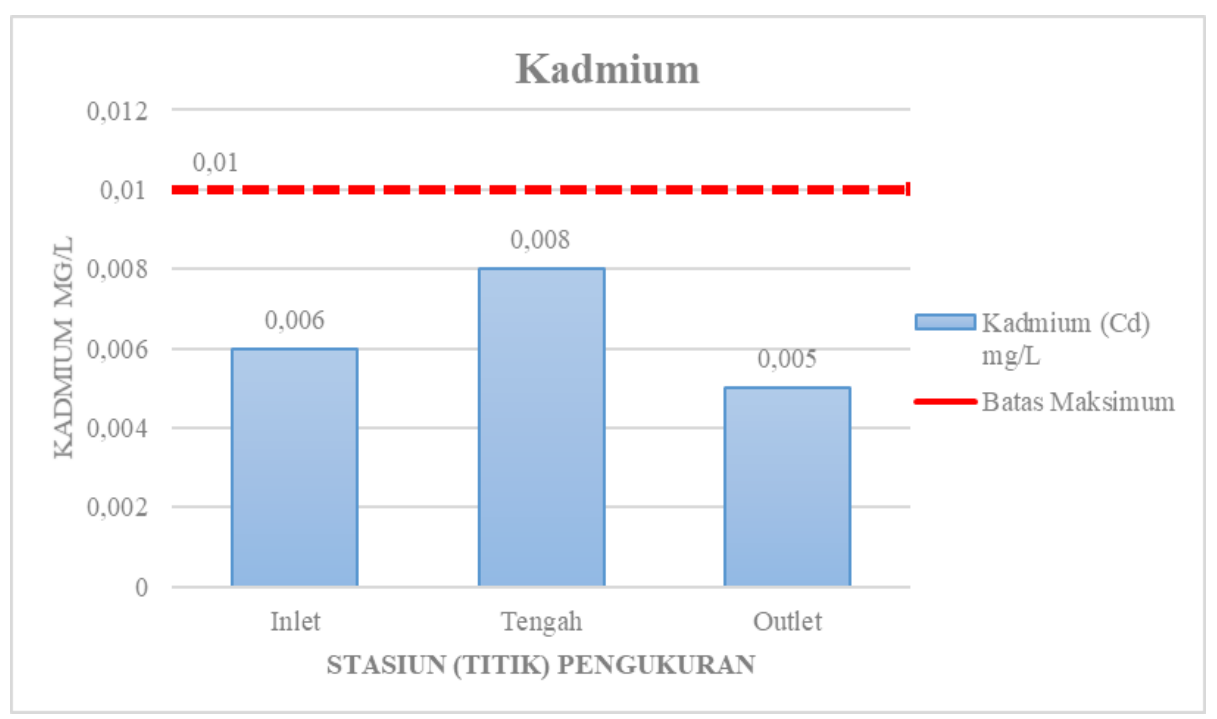

GAMBAR 9. Histogram Kadmium Air Danau Sunter

Pada Hasil pengukuran Kadmium di tiga stasiun (titik) pada perairan Danau Sunter menunjukkan variasi nilai yang kecil dan perbedaan tidak terlalu besar yaitu $0,005-0,008 \mathrm{mg} / \mathrm{L}$. Rata-rata nilai Kadmium dari ketiga titik pengukuran adalah $0,0063 \mathrm{mg} / \mathrm{L}$. Nilai terendah terdapat pada titik outlet yaitu $0,005 \mathrm{mg} / \mathrm{L}$ dan nilai tertinggi pada titik tengah dengan nilai $0,008 \mathrm{mg} / \mathrm{L}$. Berdasarkan gambar 9 di atas, hasil pengukuran Kadmium di tiga titik mengalami grafik fluktuatif yang nilainya tidak terlalu signifikan. Berdasarkan Peraturan Pemerintah Nomor 82 Tahun 2001, kisaran batas maksimum Kadmium untuk kelas 3 adalah $0,01 \mathrm{mg} / \mathrm{L}$. Dengan demikian, hasil uji parameter Kadmium Danau Sunter masih memenuhi kriteria dengan tidak melebihi batas maksimum baku mutu yang dipersyaratkan.

Kadmium (Cd) merupakan logam berat yang sampai saat ini belum diketahui dengan jelas peranannya bagi tumbuhan dan makhluk hidup lainnya. Kadmium bersifat tidak larut dalam air, memiliki ukuran yang sangat kecil $\pm 0,65$ mikron dan bersifat toksik. Kadmium banyak digunakan dalam industri metalurgi, pelapisan logam, pigmen, gelas, keramik, tekstil, dan plastik [18]. Logam berat Kadmium yang kadarnya masih di bawah ambang batas untuk pemeliharaan air tawar di sekitar Danau Sunter masih dapat dikontrol dan perairannya juga dapat digunakan untuk pemeliharaan ikan. Tidak ada penelitian lebih lanjut observasi mengenai ikan air tawar yang berasal dari Danau Sunter untuk di ketahui kandungan Kadmiumnya, sehingga masih aman untuk kepentingan budidaya.

\section{Tembaga}

Sebaran nilai hasil uji parameter Tembaga air Danau Sunter dapat dilihat pada GAMBAR 10 di bawah ini. 


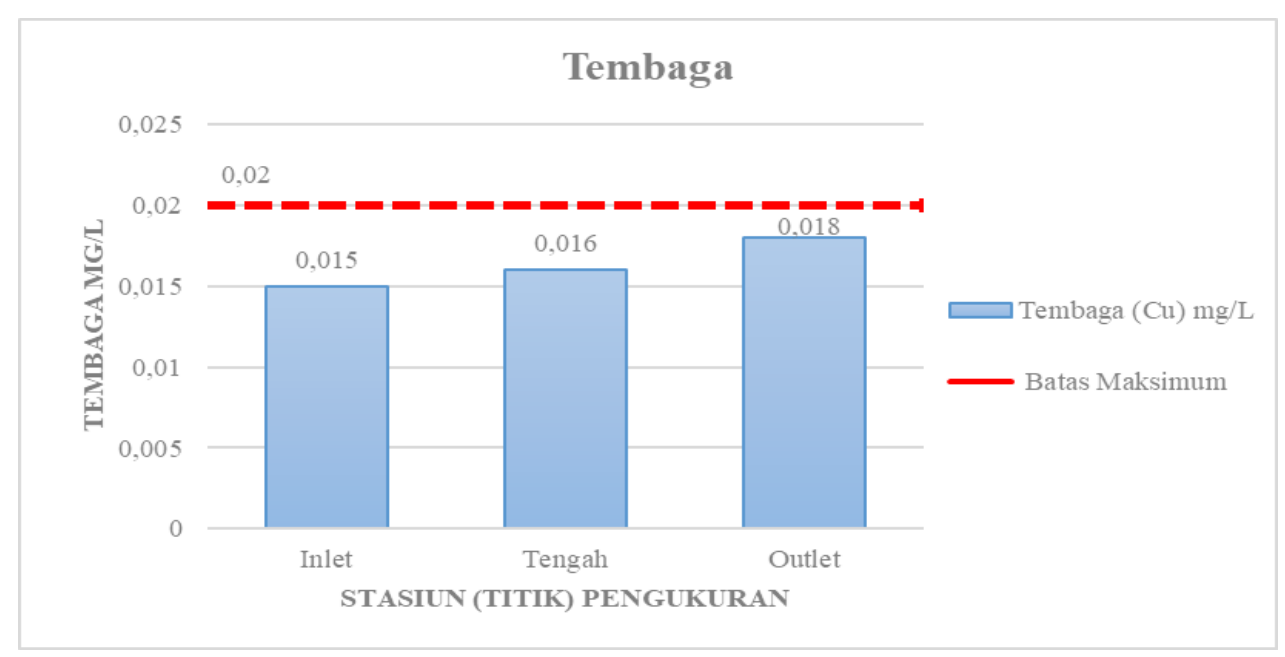

GAMBAR 10. Histogram Tembaga Air Danau Sunter

Pada Hasil pengukuran Tembaga di tiga stasiun (titik) pada perairan Danau Sunter menunjukkan variasi nilai yang kecil dan perbedaan tidak terlalu besar yaitu $0,015-0,018 \mathrm{mg} / \mathrm{L}$. Rata-rata nilai Tembaga dari ketiga titik pengukuran adalah $0,0163 \mathrm{mg} / \mathrm{L}$. Nilai terendah terdapat pada titik inlet yaitu $0,015 \mathrm{mg} / \mathrm{L}$ dan nilai tertinggi pada titik outlet dengan nilai $0,018 \mathrm{mg} / \mathrm{L}$. Berdasarkan gambar 10 di atas, hasil pengukuran Tembaga di tiga titik mengalami grafik peningkatan yang nilainya tidak terlalu signifikan. Berdasarkan Peraturan Pemerintah Nomor 82 Tahun 2001, kisaran batas maksimum Tembaga untuk kelas 3 adalah $0,02 \mathrm{mg} / \mathrm{L}$. Dengan demikian, hasil uji parameter Tembaga Danau Sunter masih memenuhi kriteria dengan tidak melebihi batas maksimum baku mutu yang dipersyaratkan.

Tembaga $(\mathrm{Cu})$ merupakan logam berat yang bersifat racun. Keberadaan $\mathrm{Cu}$ dalam perairan dapat terakumulasi di dalam rantai makanan dan menimbulkan efek yang berbahaya. Logam berat juga memiliki daya oligodinamik yaitu memiliki daya bunuh pada konsentrasi rendah [10].

Logam berat Tembaga yang kadarnya masih di bawah ambang batas untuk pemeliharaan air tawar di sekitar Danau Sunter masih dapat dikontrol dan perairannya juga dapat digunakan untuk pemeliharaan ikan. Tidak ada penelitian lebih lanjut observasi mengenai ikan air tawar yang berasal dari Danau Sunter untuk di ketahui kandungan Tembaganya, sehingga masih aman untuk kepentingan budidaya.

\section{Nitrit}

Sebaran nilai hasil uji parameter Nitrit air Danau Sunter dapat dilihat pada GAMBAR 11 di bawah ini. 


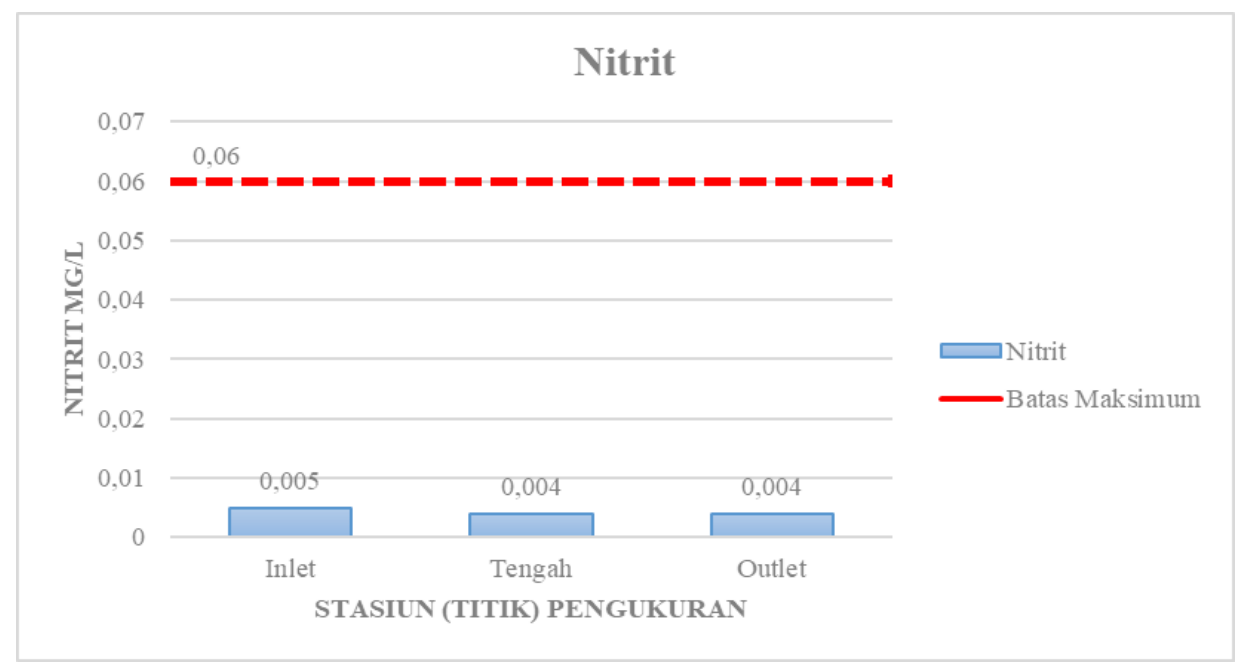

GAMBAR 11. Histogram Nitrit Air Danau Sunter

Pada Hasil pengukuran Nitrit di tiga stasiun (titik) pada perairan Danau Sunter menunjukkan variasi nilai yang tidak terlalu besar yaitu $0,004-0,005 \mathrm{mg} / \mathrm{L}$. Rata-rata nilai Nitrit dari ketiga titik pengukuran adalah $0,0043 \mathrm{mg} / \mathrm{L}$. Nilai terendah terdapat pada titik tengah dan outlet yaitu 0,004 $\mathrm{mg} / \mathrm{L}$ dan nilai tertinggi pada titik inlet dengan nilai $0,005 \mathrm{mg} / \mathrm{L}$. Berdasarkan gambar 11 di atas, hasil pengukuran Nitrit di tiga titik mengalami grafik penurunan yang nilainya tidak terlalu signifikan. Berdasarkan Peraturan Pemerintah Nomor 82 Tahun 2001, kisaran batas maksimum Nitrit untuk kelas 3 adalah 0,06 mg/L. Dengan demikian, hasil uji parameter Nitrit Danau Sunter masih memenuhi kriteria dan tidak melebihi batas maksimum baku mutu yang dipersyaratkan.

Nitrit (NO2) merupakan bentuk nitrogen yang hanya sebagian teroksidasi. Nitrit tidak ditemukan dalam air limbah yang segar, melainkan dalam limbah yang sudah basi atau lama. Sumber nitrit dapat berupa limbah industri dan limbah domestik. Kadar nitrit di perairan relatif sedikit, tidak tetap dan dapat berubah menjadi amonia atau dioksidasi menjadi nitrat [12]. Kadar yang sedikit tersebut dikarenakan senyawa nitrit berada pada fase pertengahan proses nitrifikasi dan denitrifikasi.

Konsentrasi Nitrit pada perairan Danau Sunter yang di kategorikan rendah dari inlet hingga outlet menunjukkan masa tinggal air dalam danau yang tinggi karena outlet yang jauh dari daerah inlet. Pada perairan, konsentrasi nitrit dijumpai dalam konsentrasi yang lebih rendah dari konsentrasi nitrat. Hal ini disebabkan karena bentuk senyawa nitrit yang bersifat tidak stabil dan akan segera teroksidasi jika kandungan oksigen terlarut mencukupi. Kandungan oksigen terlarut di daerah inlet mempengaruhi oksidasi nitrit menjadi nitrat, khususnya di daerah sekitar Danau Sunter tersebut.

Kondisi kualitas air Danau Sunter yaitu sifat air dan kandungan makhluk hidup, zat energi atau komponen lain. Berdasarkan beberapa parameter dalam pembahasan di atas yaitu parameter fisika (Suhu, Kekeruhan, TDS dan TSS. Parameter kimia (pH, DO, BOD, COD, Kadmium, Tembaga, dan Nitrit. Semua masih dalam kondisi yang dapat dikontrol dan masih sesuai peruntukannya. Terdapat dua parameter baku mutu air yang melebihi batas persyaratan kualitas air kelas 3 atau golongan $\mathrm{c}$ yaitu suhu dan BOD.

\section{Indeks Pencemaran (IP) Danau Sunter}

Indeks pencemaran digunakan untuk menentukan tingkat pencemaran relatif terhadap parameter kualitas air yang diizinkan. Indeks ini berkaitan dengan senyawa pencemar yang bermakna untuk suatu peruntukan dan dapat dikembangkan untuk beberapa peruntukan bagi seluruh bagian badan air atau sebagian [12].

Dalam penelitian ini perhitungan indeks pencemaran didasarkan pada titik pengambilan sampel dan pada parameter yang telah ditentukan yaitu parameter fisika dan parameter kimia. Pada parameter fisika meliputi Suhu, Kekeruhan, TDS, dan TSS. Pada parameter kimia meliputi pH, DO, BOD, COD, Kadmium, Tembaga, dan Nitrit. Baku mutu air yang digunakan adalah berdasarkan Peraturan Pemerintah Nomor 82 Tahun 2001 tentang Pengelolaan Kualitas Air dan Pengendalian 
Pencemaran Air Kelas 3, dan Keputusan Gubernur DKI Jakarta Nomor 582 Tahun 1995 Tentang Penetapan Peruntukan dan Baku Mutu Air Sungai/Badan Air serta Baku Limbah Cair di Wilayah DKI Jakarta golongan C khusus parameter Kekeruhan.

Tabel 3. Hasil Perhitungan Indeks Pencemaran Danau Sunter April 2019

\begin{tabular}{clccc}
\hline \multirow{2}{*}{ No } & \multirow{2}{*}{ Stasiun (Titik) Pengambilan Sampel } & \multicolumn{2}{c}{ Indeks Pencemaran } \\
\cline { 3 - 4 } & & Nilai & Keterangan \\
\hline 1 & Inlet & 1,71 & Tercemar Ringan \\
\hline 2 & Tengah & 1,77 & Tercemar Ringan \\
\hline 3 & Outlet & 1,78 & Tercemar Ringan \\
\hline
\end{tabular}

Berdasarkan hasil perhitungan indeks pencemaran pada tabel 3 di atas dapat disimpulkan bahwa kualitas perairan Danau Sunter pada bulan April 2019 mulai dari masukan aliran air atau inlet hingga ke keluaran aliran air atau outlet mengalami penurunan kualitas (meningkatnya nilai indeks pencemaran) di mana rata-ratanya adalah tercemar ringan. Pencemaran perairan Danau Sunter terjadi disebabkan karena kandungan BOD dan Suhu yang telah melebihi ambang batas yang telah ditetapkan.

Berdasarkan Peraturan Pemerintah Nomor 82 Tahun 2001 dan Keputusan Gubernur DKI Jakarta Nomor 582 Tahun 1995, dengan kualitas air seperti tersebut di atas maka Danau Sunter secara umum masih dapat dimanfaatkan untuk pembudidayaan air tawar, peternakan, air untuk mengairi pertanaman, dari untuk peruntukan lain yang mempersyaratkan mutu air yang sama dengan kegunaan tersebut.

Sebagai evaluasi mutu air Danau Sunter dilakukan berdasarkan hasil pemantauan kualitas air bulan april tahun 2019 dengan perhitungan indeks pencemaran dan didasarkan pada titik pengambilan sampel pada inlet, tengah, maupun outlet serta parameter yang sudah ditentukan yaitu Suhu, Kekeruhan, TDS, TSS, pH, DO, BOD, COD, Kadmium, Tembaga, dan Nitrit. Dari hasil perhitungan menunjukkan kondisi kualitas air Danau Sunter yang rata-rata sudah tercemar ringan. Hal ini ditunjukkan oleh nilai indeks pencemaran yang lebih dari 1,00. Kondisi kualitas air yang sudah tercemar memerlukan upaya pengendalian pencemaran untuk mengembalikan kualitas air agar dapat dimanfaatkan sesuai dengan peruntukannya dengan baik.

\section{SIMPULAN}

Kualitas air Danau Sunter Berdasarkan uji parameter pencemaran air dari arah inlet hingga outlet secara keseluruhan masih dalam kondisi baik. Hanya saja ada dua parameter yang kondisinya tidak sesuai dengan peruntukan baku mutu air kelas 3 atau golongan C yaitu Suhu dan BOD. Kualitas air Danau Sunter berdasrkan penilaian status mutu air dengan metode indeks pencemaran menunjukkan semua stasiun atau titik pengambilan sampel dari inlet hingga outlet dalam kondisi tercemar ringan

\section{UCAPAN TERIMAKASIH}

Terimakasih kepada Dinas Lingkungan Hidup Provinsi DKI Jakarta yang telah menunjang pengambilan data pada penelitian ini.

\section{REFERENSI}

[1] J. P. Rares, M. Sholichin and E. Yuliani, "Analisis Pengelolaan Kualitas Air Di Perairan Danau Tondano,” J. Tek. Pengair, vol. 7, pp. 225-235, 2016.

[2] C. B. H. Edyanto, "Penelitian Kualitas Air Danau Aneuk Laot Di Pulau Weh Propinsi Nangroe Aceh Darussalam,” J. Tek. Lingkung, pp. 115-124, 2006.

[3] D. Hendrawan, "Kualitas Air Sungai Dan Situ Di Dki Jakarta," MAKARA Technol. Ser, vol. 9, no. 1, pp. 13-19, 2010. 
[4] S. A. Putro, Ashadi and L. Hakim, "Penerapan Konsep Arsitektur Ekologi pada Perancangan Kawasan Wisata Air Danau Sunter di Jakarta," J. Arsit. PURWARUPA, vol. 2, pp. 19-24, 2018.

[5] F. Tatangindatu, O. Kalesaran and R. Rompas, "Studi Parameter Fisika Kimia Air pada Areal Budidaya Ikan di Danau Tondano, Desa Paleloan, Kabupaten Minahasa," e-Journal Budid. Perair, vol. 1, no. 2, pp. 8-19, 2013.

[6] A. Ali, "Kajian Kualitas Air Dan Status Mutu Air Sungai Metro Di Kecamatan Sukun Kota Malang," Bumi Lestari, vol. 13, no. 2, pp. 265-274, 2013.

[7] B. Hamuna et al., "Kajian Kualitas Air Laut dan Indeks Pencemaran Berdasarkan Parameter Fisika-Kimia di Perairan Distrik Depapre, Jayapura," J. Ilmu Lingkung, vol. 16, no. 1, p. 35, 2018.

[8] P. A. Urbasa, S. L. Undap and R. J. Rompas, "Dampak Kualitas Air Pada Budi Daya Ikan Dengan Jaring Tancap Di Desa Toulimembet Danau Tondano," J. Bidudaya Perair, vol. 3, no. 1, pp. 59-67, 2015.

[9] M. S. Syawal, Y. Wardiatno and S. Hariyadi, "Pengaruh Aktivitas Antropogenik Terhadap Kualitas Air, Sedimen dan Moluska di Danau Maninjau Sumatera Barat Jurnal Biologi Tropis, Januari 2016: Volume 16 (1):1-14 ISSN: 1411-9587,” J. Biol. Trop, vol. 16, no. 1, pp. 1-14, 2016.

[10] S. Bahri, F. Ramadhan and I. Reihannisa, "Kualitas Perairan Situ Gintung, Tangerang Selatan,” Biog. J. Ilm. Biol, vol. 3, no. 1, pp. 16-22, 2015.

[11] F. Irwan and A. Afdal, "Analisis Hubungan Konduktivitas Listrik Dengan Total Dissolved Solid (TDS) Dan Temperatur Pada Beberapa Jenis Air,” J. Fis. Unand, vol. 5, no. 1, pp. 8593, 2016.

[12] E. Yuliastuti, "Kajian Kualitas Air Sungai Ngringo Karanganyar dalam upaya Pengendalian Pencemaran Air," 2011.

[13] H. N. Silalahi, M. Manaf and A. Alianto, "Status Mutu Kualitas Air Laut Pantai Maruni Kabupaten Manokwari," J. Sumberd. Akuatik Indopasifik, vol. 1, no. 1, p. 33, 2017.

[14] N. Zaharuddin, W. Hesti and M. Ahmad, "Penentuan Kualitas Air di Danau Kelapa Gading Kelurahan Kisaran Naga Kabupaten Asahan Provinsi Sumatera Utara," Manaj. Sumberd. Perairan, Univ. Sumatera Utara, 2015.

[15] T. Hardiyanti, "Analisis Kuantitas Dan Kualitas Air Danau Unhas Sebagai Sumber Air Baku Ipa Unhas,” J. Penelit, vol. 3, no. 1, pp. 1-10, 2015.

[16] T. A. Barus, "Faktor-Faktor Lingkungan Abiotik dan Keanekaragaman Plankton sebagai Indikator Kualitas Perairan Danau Toba (Environmental Abiotic Factors and the Diversity of Plnnkton as Water Quality Indicators in Lake Toba, Nort Sumatera, Indonesia)," Mns. dan Lingkung, vol. 11, no. 2, pp. 64-72, 2004.

[17] N. El Fajri and A. Kasry, "Kualitas Perairan Muara Sungai Siak Ditinjau Dari Sifat FisikKimia dan Makrozoobentos," Berk. Perikan. Terubuk, vol. 41, no. 1, pp. 37-52, 2013.

[18] S. Yudo, "Kondisi Pencemaran Logam Berat Di Perairan Sungai Dki Jakarta," J. Air Indones, vol. 2, no. 1, pp. 1-15, 2006. 
